\title{
Front Matter: Volume 10777
}

, "Front Matter: Volume 10777," Proc. SPIE 10777, Land Surface and Cryosphere Remote Sensing IV, 1077701 (28 November 2018); doi: 10.1117/12.2520635

SPIE Event: SPIE Asia-Pacific Remote Sensing, 2018, Honolulu, Hawaii, United SPIE. States 


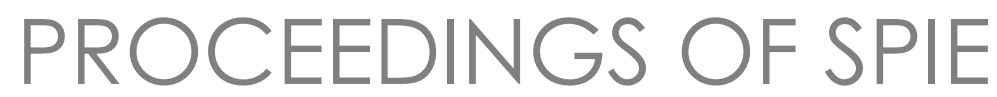

\title{
Land Surface and Cryosphere Remote Sensing IV
}

\author{
Mitchell Goldberg \\ Jing M. Chen \\ Reza Khanbilvardi \\ Editors
}

\section{5-26 September 2018 \\ Honolulu, Hawaii, United States}

Sponsored by

SPIE

Cosponsored by

NASA-National Aeronautics and Space Administration (United States)

RADI-Institute of Remote Sensing and Digital Earth, Chinese Academy of Sciences (China)

State Key Laboratory of Remote Sensing Science, Chinese Academy of Sciences (China)

Ministry of Earth Sciences (India)

Cooperating Organizations

University of Hawai'i at Mānoa (United States)

JAXA-Japan Aerospace Exploration Agency (Japan)

NICT-National Institute of Information and Communications Technology (Japan)

ISRO_-Indian Space Research Organization (India)

ESSO-Earth System Science Organization (India)

Published by

SPIE

Volume 10777 
The papers in this volume were part of the technical conference cited on the cover and title page. Papers were selected and subject to review by the editors and conference program committee. Some conference presentations may not be available for publication. Additional papers and presentation recordings may be available online in the SPIE Digital Library at SPIEDigitalLibrary.org.

The papers reflect the work and thoughts of the authors and are published herein as submitted. The publisher is not responsible for the validity of the information or for any outcomes resulting from reliance thereon.

Please use the following format to cite material from these proceedings:

Author(s), "Title of Paper," in Land Surface and Cryosphere Remote Sensing IV, edited by

Mitchell Goldberg, Jing M. Chen, Reza Khanbilvardi, Proceedings of SPIE Vol. 10777 (SPIE, Bellingham, WA, 2018) Seven-digit Article CID Number.

ISSN: 0277-786X

ISSN: 1996-756X (electronic)

ISBN: 9781510621299

ISBN: 9781510621305 (electronic)

Published by

SPIE

P.O. Box 10, Bellingham, Washington 98227-0010 USA

Telephone +1 3606763290 (Pacific Time) · Fax +1 3606471445

SPIE.org

Copyright (C) 2018, Society of Photo-Optical Instrumentation Engineers.

Copying of material in this book for internal or personal use, or for the internal or personal use of specific clients, beyond the fair use provisions granted by the U.S. Copyright Law is authorized by SPIE subject to payment of copying fees. The Transactional Reporting Service base fee for this volume is $\$ 18.00$ per article (or portion thereof), which should be paid directly to the Copyright Clearance Center (CCC), 222 Rosewood Drive, Danvers, MA 01923. Payment may also be made electronically through CCC Online at copyright.com. Other copying for republication, resale, advertising or promotion, or any form of systematic or multiple reproduction of any material in this book is prohibited except with permission in writing from the publisher. The CCC fee code is 0277$786 \mathrm{X} / 18 / \$ 18.00$.

Printed in the United States of America.

Publication of record for individual papers is online in the SPIE Digital Library.

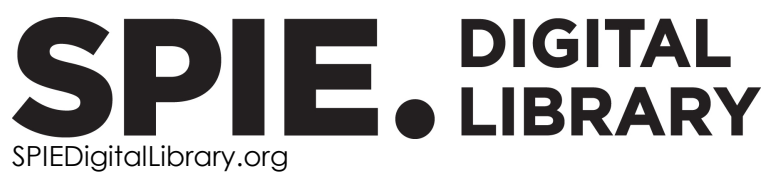

Paper Numbering: Proceedings of SPIE follow an e-First publication model. A unique citation identifier (CID) number is assigned to each article at the time of publication. Utilization of CIDs allows articles to be fully citable as soon as they are published online, and connects the same identifier to all online and print versions of the publication. SPIE uses a seven-digit CID article numbering system structured as follows:

- The first five digits correspond to the SPIE volume number.

- The last two digits indicate publication order within the volume using a Base 36 numbering system employing both numerals and letters. These two-number sets start with $00,01,02,03,04$, 05, 06, 07, 08, 09, 0A, OB ... 0Z, followed by 10-1Z, 20-2Z, etc. The CID Number appears on each page of the manuscript. 


\title{
Contents
}

\author{
$\checkmark \quad$ Authors \\ vii Symposium Committees \\ ix Conference Committee
}

REMOTE SENSING OF LAND SURFACE TEMPERATURE

10777 OC Spatial analysis of the Surface Urban Heat Island [10777-11]

REMOTE SENSING OF SOIL MOISTURE

10777 OG Soil directional (biconical) reflectance in the principal plane with varied illumination angle under dry and saturated conditions [10777-20]

$10777 \mathrm{OH}$ Preliminary study on the applicability of several remote sensing drought indices to agricultural drought monitoring in Gansu province of China [10777-21]

REMOTE SENSING OF VEGETATION TRAITS AND FUNCTION

$10777 \mathrm{OL} \quad$ Dynamic mapping of broadband visible albedo of soil background at global 500-m scale from MODIS satellite products [10777-28]

10777 OM Canopy conductance index for GPP estimation from it's capacity [10777-29]

10777 ON Using model-data fusion to downscale solar-induced fluorescence data into a higher spatiotemporal resolution [10777-30]

FOREST MANAGEMENT AND SAR APPLICATION

1077700 Spatio-temporal dynamics of shifting cultivation in Upland Myanmar using time series images and implications for REDD+ [10777-31] 
10777 OR Using the UAV-derived NDVI to evaluate spatial and temporal variation of crop phenology at crop growing season in South Korea [10777-35]

10777 OT Research on remote sensing information and WheatSM model-based winter wheat yield estimation [10777-39]

10777 OU Remote sensing and GIS model for food security mapping in Gunungkidul Regency Daerah Istimewa Yogyakarta [10777-40]

\section{POSTER SESSION}

10777 OX Evaluating observation and modeling of net radiation based on remote sensing data and CoLM [10777-10]

10777 OY NDVI and RVI-based dry hot wind comparative monitoring research [10777-16]

$107770 Z$ Estimation of summer corn leaf area index in Yucheng County of Shandong Province, China [10777-37]

107715 Reflectance comparison between Himawari-8 AHI and Terra MODIS over a forest of Shikoku region [10777-48]

1077718 Paddy rice inventory studies using drone imagery on a small town area in South Korea [10777-53] 


\title{
Authors
}

Numbers in the index correspond to the last two digits of the seven-digit citation identifier (CID) article numbering system used in Proceedings of SPIE. The first five digits reflect the volume number. Base 36 numbering is employed for the last two digits and indicates the order of articles within the volume. Numbers start with 00, 01, 02, 03, 04, 05, 06, 07, 08, 09, 0A, 0B...0Z, followed by 10-1Z, 20-2Z, etc.

\author{
Adachi, Yusuke, 15 \\ Asrar, Ghassem, ON \\ Cai, Wenting, $\mathrm{OZ}$ \\ Chen, Huai-Liang, OT, OY \\ Chen, Min, ON \\ Fang, Wensong, OY \\ Fu, Zhuo, OX \\ Gao, Lijing, OX \\ $\mathrm{Hu}, \mathrm{Die}, \mathrm{OH}$ \\ Ichii, Kazuhito, 15 \\ Kikuchi, Ryota, 15 \\ Lee, Dong-Ho, OR, 18 \\ $\mathrm{Li}$, Tongxiao, OT \\ Li, Ying, OT, OY \\ $\mathrm{Li}$, Yiping, $\mathrm{OH}$ \\ Liu, Liangyun, OL \\ Liu, Yun, ON \\ Lu, Heli, 00 \\ Lu, Siqi, 00 \\ Matsuoka, Masayuki, 15 \\ McGrath, Gavan S., OC \\ Muramatsu, Kanako, OM \\ Murti, Sigit Heru, OU \\ Park, Jin-Ki, OR, 18 \\ Park, Jong-Hwa, OR, 18 \\ Philpot, William, OG \\ Rao, P. Suresh C., OC \\ Sha, Sha, $\mathrm{OH}$ \\ Shen, Zhanfeng, $0 X$ \\ Shin, Heong-Seup, 18 \\ Shin, Kyong-Ho, OR \\ Shreevastava, Anamika, OC \\ Tian, Hongwei, OT \\ Tian, Jia, OG \\ Wang, Lijuan, $\mathrm{OH}$ \\ Wang, Yamei, $\mathrm{OZ}$ \\ Yoshioka, Hiroki, 15 \\ Zeng, Ning, ON \\ Zhang, Chuanrong, 00 \\ Zhang, Xiao, $\mathrm{OL}$ \\ Zhang, YU, OT, OY \\ Zhao, Lifang, OX \\ Zhao, Shuhe, $\mathrm{OZ}$ \\ Zhou, Hongkui, $\mathrm{OZ}$
}


Proc. of SPIE Vol. 10777 1077701-6

Downloaded From: https://www.spiedigitallibrary.org/conference-proceedings-of-spie on 26 Apr 2023 Terms of Use: https://www.spiedigitallibrary.org/terms-of-use 


\title{
Symposium Committees
}

\author{
Symposium Chair
}

Upendra Singh, NASA Langley Research Center (United States)

Symposium Co-chairs

Toshiyoshi Kimura, Japan Aerospace Exploration Agency (Japan)

K. J. Ramesh, Ministry of Earth Sciences (India)

Jiancheng Shi, Institute of Remote Sensing and Digital Earth (China)

Honorary Symposium Chairs

Huadong Guo, Institute of Remote Sensing and Digital Earth (China)

Stephen Jurczyk, National Aeronautics and Space Administration (United States)

A. S. Kiran Kumar, Indian Space Research Organisation (India)

Jean-Yves Le Gall, Centre National d'Études Spatiales (France)

Robert M. Lightfoot, Jr., National Aeronautics and Space

Administration (United States)

Madhavan N. Rajeevan, Ministry of Earth Sciences (India)

Alain Ratier, EUMETSAT (Germany)

Hiroshi Yamakawa, Japan Aerospace Exploration Agency (Japan)

Symposium International Organizing Committee

Michael H. Freilich, Chair, National Aeronautics and Space Administration (United States)

Jack A. Kaye, National Aeronautics and Space Administration (United States)

Barry L. Lefer, National Aeronautics and Space Administration (United States)

Clayton P. Turner, NASA Langley Research Center (United States)

Pamela Millar, NASA Goddard Space Flight Center (United States)

David F. Young, NASA Langley Research Center (United States)

Tapsan Misra, Indian Space Research Organisation (India)

Kazuo Tachi, Japan Aerospace Exploration Agency (Japan) 
Katsuhiro Nakagawa, National Institute of Information and

Communications Technology (Japan)

Haruhisa Shimoda, Tokai University (Japan)

Kohei Mizutani, National Institute of Information and

Communications Technology (Japan)

Wonkook Kim, Korea Institute of Ocean Science and Technology (Republic of Korea)

YoungJe Park, Korea Institute of Ocean Science and Technology (Republic of Korea)

Jhoon Kim, Yonsei University (Republic of Korea)

Xianqiang He, Second Institute of Oceanography, State Oceanic Administration (China)

Shunling Liang, Beijing Normal University (China) 


\title{
Conference Committee
}

\author{
Conference Chairs
}

Mitchell Goldberg, Joint Polar Satellite System (United States)

Jing M. Chen, University of Toronto (Canada)

Reza Khanbilvardi, The City University of New York (United States)

Conference Program Committee

Ghassem Asrar, U.S. Dept. of Energy (United States)

Bimal K. Bhattacharya, Space Applications Center (India)

Dara Entekhabi, Massachusetts Institute of Technology (United States)

Ashwagosh Ganju, Defence Research and Development Organisation (India)

Peng Gong, Tsinghua University (China)

Koji Kajiwara, Chiba University (Japan)

Venkat Lakshmi, University of South Carolina (United States)

Zhao-Liang Li, Institute of Geographic Sciences and Natural Resources Research (China)

Shunlin Liang, University of Maryland, College Park (United States)

Kyle C. McDonald, Jet Propulsion Laboratory (United States)

Thamban Meloth, National Center for Antarctic \& Ocean Research (India)

Ashim Kumar Mitra, Ministry of Earth Sciences (India)

A. S. Rajawat, Space Applications Center (India)

M. Rajeevan, Indian Institute of Tropical Meteorology (India)

Peter Romanov, Center for Satellite Applications and Research (United States)

Kamal Vatta, Centers for International Projects Trust (India)

Session Chairs

1 Remote Sensing of Glaciers

Mitchell D. Goldberg, Joint Polar Satellite System (United States)

2 Remote Sensing of Wildfire, Soil Erosion, Landslide, and Hot Wind

Yifang Ban, KTH Royal Institute of Technology (Sweden)

3 Remote Sensing of Land Surface Temperature

Anamika Shreevastava, Purdue University (United States)

$4 \quad$ Remote Sensing of Soil Moisture

Venkat Lakshmi, University of South Carolina (United States) 
5 Remote Sensing of Vegetation Traits and Function

Wenjiang Huang, Institute of Remote Sensing and Digital Earth (China)

6 Forest Management and SAR Application Andreas Colliander, Jet Propulsion Laboratory (United States)

7 Remote Sensing Applications to Agriculture and Other Surfaces Liangyun Liu, Institute of Remote Sensing and Digital Earth (China) 